\title{
«A memorização de pedaço chave da nossa história». Nota a propósito da apresentação pública da obra 1961: Memória de um ano decisivo
}

\section{Gustavo Costa}

\author{
(2) OpenEdition \\ Journals \\ Edição electrónica \\ URL: http://journals.openedition.org/mulemba/437 \\ DOI: $10.4000 /$ mulemba.437 \\ ISSN: 2520-0305 \\ Editora \\ Edições Pedago \\ Edição impressa \\ Data de publição: 1 maio 2015 \\ Paginação: 509-513 \\ ISSN: 2182-6471 \\ Refêrencia eletrónica \\ Gustavo Costa, ««A memorização de pedaço chave da nossa história». Nota a propósito da \\ apresentação pública da obra 1961: Memória de um ano decisivo», Mulemba [Online], 5 (9) | 2015, \\ posto online no dia 22 novembro 2016, consultado o 26 janeiro 2021. URL: http:// \\ journals.openedition.org/mulemba/437 ; DOI: https://doi.org/10.4000/mulemba.437
}

Este documento foi criado de forma automática no dia 26 janeiro 2021.

Tous droits réservés 


\title{
«A memorização de pedaço chave da nossa história». Nota a propósito da apresentação pública da obra 1961: Memória de um ano decisivo
}

\author{
Gustavo Costa
}

\section{NOTA DO AUTOR}

Texto da apresentação pública da obra 1961: Memória de um ano decisivo (Luanda, ATD Associação Tchiweka de Documentação, 2015, 204p.), que teve lugar no Museu Nacional de História Militar (Fortaleza de São Miguel), em Luanda, no dia 12 de Março de 2015.

1 Confrontado com a magnitude dos Trilhos da Independência, que a Associação Tchiweka entendeu oferecer-nos como uma das mais recentes e valiosas peças do nosso acervo histórico-político, deixem-me dizer-vos, em primeiro lugar, que tenho sérias dúvidas se, perante a minha pequenez, serei a pessoa mais indicada para fazer a apresentação desta compilação de textos, como modestamente lhe chama a Wanda, ${ }^{1}$ focalizada no ano decisivo de 1961.

2 Por isso, num primeiro instante, confesso que hesitei em aceitar tão honroso convite e abraçar tamanha responsabilidade. Quis, no entanto, a Wanda que o fizesse.

E, perante o desafio dela, ao mergulhar nas raízes das histórias trilhadas nas cento e noventa e oito páginas daquilo que pode ser já o maior espólio documental reunido até hoje à volta da nossa narrativa independentista, não pude resistir à amplitude de uma utopia que se consagrou na nossa maior saga: a conquista da Independência!

4 Não resisti também ao pioneirismo de um trabalho de investigação de uma envergadura ímpar, que tem o DNA de um nacionalista cuja grandeza se confunde com a epopeia de 
milhares de angolanos que, naquele tempo, há mais de cinquenta anos, cada um à sua maneira, deram o melhor de si para abrirem os caboucos do nosso edifício pátrio.

Por essa razão, as fotografias, os vídeos e as gravações, mais do que o acervo e o legado do nacionalista Lúcio Lara, são a expressão do grito de alma de uma imensa geração depositária dos mais nobres valores do nosso moderno nacionalismo.

6 Foi por essa razão que, desde o primeiro momento, entre Fevereiro de 2011 e Janeiro de 2012, a equipa do Novo Jornal ${ }^{2}$ da qual eu fazia parte, se associou, incondicionalmente, a esta iniciativa.

7 Contagiado pela sua dimensão, o Novo Jornal de então abriu-lhe as páginas e, assumindose cúmplice da mesma causa, paginadores e jornalistas, entenderam contribuir, de forma modesta, para a sua visibilidade ao irradiar grafismos e afins extraordinários para um projecto que era então uma esperança e um sonho e que, agora, se tornou realidade.

8 Esta é uma obra que não foi gerada por nenhuma universidade, nem recebeu o concurso de nenhuma consultoria estrangeira, como agora, exageradamente, virou moda.

9 Também não foi escrita por nenhum jornalista insigne, que quase já não os há, nem por jovens engravatados que, falando de cátedra, da história têm a mesma vaga noção que alguns dos nossos novos ricos têm da pobreza...

10 Estamos perante uma arma poderosa, que resistiu a todas as tentativas de rasura da história da Independência e mesmo a certas correntes negacionistas, que gostariam de ver triunfada aqui uma narração «descafeinada».

11 Se essa narração se impusesse, não sejamos inocentes, prevaleceria a manipulação da verdade através de uma subtil selecção de acontecimentos, que daria lugar à criação de mitos para justificar doutrinas e práticas do passado e do presente.

12 Se essa narração triunfasse, assistiríamos, não tenhamos ilusões, a exclusão de partes da nossa memória colectiva e de grupos mais sensíveis, tais como as minorias étnicas, políticas, religiosas ou raciais.

13 A Associação Tchiweka preferiu a Nação e decidiu memorizar um pedaço chave da nossa história cuja riqueza assenta na sua transversalidade.

14 Nele estão projectados depoimentos e fotos memoráveis de patriotas angolanos, de outros combatentes africanos anti-colonialistas e também de anti-fascistas portugueses, que decidiram solidarizar-se com a causa angolana.

15 Não há aqui, nesta obra, angolanos da UPA, ${ }^{3}$ da FNLA, ${ }^{4}$ do MPLA, ${ }^{5}$ da Revolta Activa, ${ }^{6}$ da Revolta do Leste ${ }^{7}$ ou da UNITA. ${ }^{8}$ Há aqui apenas angolanos! Estamos aqui, porventura, perante a viagem documental de maior fôlego nacionalista, que carrega o mérito de estar despida de estreitismos partidários ou de preconceitos de natureza tribal, étnica, racial ou religiosa.

16 Estamos perante um hino à reconciliação, escrito com poemas que afastam a exclusão $\mathrm{e}$ procuram antes irmanar passados com percursos diferentes mas todos eles trilhando o mesmo espírito.

17 Estamos perante uma obra com nome e endereço próprios, cujos testemunhos retratam os horrores da ocupação colonial, os mortos, nas cidades e nas matas, os perseguidos e os desaparecidos.

18 Estamos perante um monumento esculpido com devoção e discrição, fora dos holofotes da propaganda, feito por gente simples, modesta e abnegada, que fez desta investigação 
um desafio em busca de um passado e de um tempo que, porventura, muitos julgavam perdidos...

19 A leitura desta obra gera emoções e obriga-nos a reviver a chama do protesto que galvanizou milhares de nacionalistas de diferentes matizes políticas que, enjaulados pela $\operatorname{PIDE}^{9}$ na luta clandestina ou empunhando armas nas matas, lançaram as sementes da inesquecível gesta da libertação de Angola das grilhetas do ocupante português.

Comprometidas apenas com a história, queiram as novas gerações ler esta obra, que ajudará a compreender o passado e a iluminar o futuro, através do que a Associação Tchiweka qualificou como «folhas arquivadas, que não serão mortas, antes renovadamente ressuscitadas».

Por isso é que esta é daquelas obras que deveria figurar nos escaparates das nossas livrarias e nas galerias das bibliotecas dos nossos estabelecimentos de ensino público e privado.

Porque partiu da ideia do resgate da história, da ideia da liberdade de pensar, de fazer, de ser e de ver a história sem complexos e sem zonas de sombra ou de escuridão. Estamos, meus caros amigos, perante um notável levantamento de uma parte significativa da história, feita por uma associação que recusa, porém, ser detentora do monopólio dos seus despojos.

Por isso é que esta vasta compilação escrita, documental, iconográfica e testemunhal, feita em tempo oportuno, desafia a isenção e a liberdade dos historiadores para que persigam a investigação agora iniciada pela Associação Tchiweka.

E, porque é que os historiadores são chamados a enfrentar este desafio?

Para que as novas gerações saibam que houve um antes e um depois. Para que a geração 1980 interiorize que o passado aconteceu e não pode «desacontecer».

Para que a geração Google, aquela que tem tudo ao toque do teclado, que sabe quase tudo a respeito dos outros, não diga nunca, por nunca, que nunca ouviu falar dos horrores do colonialismo e da resistência anti-colonial protagonizada por milhares de heróis anónimos.

Obrigado Associação Tchiweka.

\section{NOTAS}

1. Wanda Lara, é subdirectora da ATD - Associação Tchiweka de Documentação e directora do Centro de Documentação Tchiweka [Nota do Editor].

2. Semanário angolano que actualmente é dirigido por Carlos Ferreira (Cassé), que, além de jornalista/radialista, é escritor membro da União dos Escritores Angolanos (UEA) [Nota do Editor].

3. União das Populações de Angola.

4. Frente Nacional de Libertação de Angola.

5. Movimento Popular de Libertação de Angola. 
6. Dissidência do MPLA. A Revolta Activa nasce na Frente Norte entre Janeiro e Abril de 1974, evidenciado após expulsão de alguns militantes do Movimento de Reajustamento e o consequente descontentamento destes. Ele torna-se bem claro em Brazzaville, sendo o seu manifesto fundamentalmente contra o presidencialismo, dito «absoluto», de Agostinho Neto [Nota do Editor].

7. Facção do MPLA, iniciada em 1969. Como o próprio nome indica, tratou-se de uma dissidência ocorrida na Frente Leste, dirigida inicialmente pelo comandante Jibóia e cujo descontentamento se deveu à preponderância dos quadros dirigentes do movimento oriundos do Norte, da 2. ${ }^{\text {a }}$ Região político-militar (Cabinda). Permanecendo uma questão entretanto mal resolvida, foi sendo mantida em fogo brando até 1972-1973, quando se evidenciou a participação de Daniel Chipenda como dirigente da referida dissidência e que levou ao seu afastamento da direcção do movimento. Contudo, os contornos da chamada Revolta do Leste mostraram-se extraordinariamente alargados, pelo que, porque os distintos posicionamentos sobre o assunto divergem, parece-nos permanecer ainda hoje insuficientemente esclarecidos [Nota do Editor].

8. União Nacional para a Independência Total de Angola.

9. Polícia Internacional e de Defesa do Estado, polícia política fascista portuguesa de repressão contra aqueles que lutavam contra a manutenção e permanência do colonialismo português, em prol da independência nacional. Surgiu em Angola em 1954 e foi substituída pela Direcção Geral de Segurança (DGS) em 1969, quando Marcello Caetano era o Presidente do Conselho de Ministros de Portugal. As suas actividades em Angola continuaram a ser exercidas até pouco tempo depois da revolução iniciada no dia 25 de Abril de 1974, que pôs fim à ditadura fascista [Nota do Editor].

\section{AUTOR}

\section{GUSTAVO COSTA}

gustavoexpresso59@gmail.com

Jornalista, ex-Director do semanário luandense Novo Jornal, e correspondente do jornal lisboeta Expresso.

É um profissional do jornalismo angolano, sendo correspondente em Luanda do jornal luso Expresso, onde assina matérias sobre o desenrolar da cena angolana na presente conjuntura. Iniciou-se no jornalismo no fim da década de 1970, já durante o período pós-independente, no Jornal de Angola, dando assim início a uma saga jornalística que o levou a servir instituições como o lendário JDM - Jornal Desportivo Militar, os diários Record e Expresso de Portugal, e pontualmente a BBC. Lançou a já extinta revista Golo, do Centro de Documentação e Informação (CDI) da então Secretaria de Estado de Educação Física e Desportos e, posteriormente, integrou a equipa que lançou o Novo Jornal, título que trouxe uma lufada de ar fresco ao panorama jornalístico nacional, e que em determinado período dirigiu. Esta publicação ganhou vários prémios e esteve associada desde o princípio ao trabalho de investigação desencadeado pela Associação Tchiweka de Documentação (ATD). 0 trabalho que esta instituição dá à estampa é uma amostra da sagacidade, do faro e da competência, traduzida na qualidade do texto, no acesso às fontes e no cruzamento de informação. Durante a sua já longa carreira em prol de um jornalismo crítico, Gustavo Costa foi galardoado com várias distinções dentre as quais o Prémio Nacional de Jornalismo e o Prémio Maboque de Jornalismo. 